\title{
LITERATURE AND ITS ROLE IN THE FORMATION OF THE NATIONS
}

\author{
Luiz Carlos Moreira da Rocha ${ }^{1}$ \\ University of Viçosa
}

\section{ABSTRACT:}

The history of any national literature mixes up with the history of its nation. One of the reasons lies in the fact that, during the process of building a nation, the issue of standard language emerges and literature plays a decisive role in the formation of both national state and standard language. Thus, this essay focus on the rise of English and American Literatures and their respective contributions to the formation of the identity of England and the U.S.A.

\section{Keywords:}

nation; literature; standard; building; identity.

\section{RESUMO:}

A história de qualquer literatura nacional se confunde com a história de sua nação. Uma das razões é o fato de que, durante a formação de um país, a questão da língua padrão emerge e sabe-se que a literatura é decisiva na formação de ambos o estado nacional e a língua nacional. Logo, este ensaio enfoca o surgimento das Literaturas Inglesa e Americana e suas respectivas contribuições para a formação da identidade da Inglaterra e dos E.U.A.

\section{Palavras-Chaves:}

nação; literatura; padrão; construção; identidade.

The history of a national literature, however much destined to be international, is part at first of the national story...

George Sampson

\footnotetext{
${ }^{1}$ Post-Doctor in Literary Studies for UFMG; Ph.D. in Science of Literature for UFRJ; Visiting Scholar at New York University (2000); Visiting Professor at Federal University of Viçosa (UFV) - MG.
} 


\section{Introduction}

When the importance of literature in the formation of any nation is at stake, the first thing that must be taken into account is that nation, as we know, is a very recent phenomenon in history. Historical accounts, archaeology and literature inform us that the profile of former societies was rather different than the ones of each modern state. The conception of modern state goes back to European Renaissance when nations, such as France and England, achieve a certain unity that allow them to forge their national identity based on some convergent facts like territory, language, political ideology and religion. Yet it is literature the institution that joins them together raising the national spirit.

Literature is an art made up of language, which has its formal and social constituents transformed to generate the writing craft. As a social institution, a national literature emerges from daily activities of the people who live in a particular area. Owing to this evidence, social institutions and individual psychology are elements ready to be represented by literary forms and contents.

This prerogative allows literature to play an important role and, in some cases, a decisive one in the formation of a nation. It is known that any country faces a struggle, normally a war, in its process of independence and, once independent, it starts dealing with those social institutions appointed above in order to ignite the process of building its cultural identity. In doing so, the rise of a national literature becomes paramount to fulfill the collective desideratum.

Notwithstanding, a national literature does not grow divorced from the previous matrix of the newly born nation. Thus, when we put the English and American experiences into historical perspective, we see that both took some time to develop the suitable forms to express the contents related to their nature, urbanity, religiosity, individual and social psychologies and other manifestations. Therefore, the following lines aim at pinpointing the most important landmarks of English and American histories recorded in literature or otherwise how literature has been contributing to shape England and America as the countries we know today.

\section{The English experience}

Considering that literature has language as its raw material and that language is one of the main factors of national integration, it is fair to state that literature is on the basis of both standard language and the formation of a nation. Taking England as an example, the three different phases of its language correspond to the gradual development of the country we know today.

"Old English" (A.D. 600-1100) or "Anglo-Saxon" was the predominant dialect of a rising country, which was, indeed, an amount of small towns, courts, villages and hamlets. The literature of that time gives us glimpses of the psychology of the English people, their way of life and gives form to religious writings, which, in turn, are other important factors of national integration. When it comes to military deeds or warfare, literature portrays the geography of the country and the attempts at its defense and expansion.

In the bulk of early national poems, some unnamed extracts written by Widsith, a scop or minstrel of the sixth century, show how biography was used as poetical material and individual psychology. Poets, in the early days of England, had public functions as they were leaders of their tribes as well as responsible for keeping their social group's memory. The oral tradition of poetic speech had, as its leading role, to bring back the past as a means of interpreting life and sustaining the actions in the present. Deor's 
Lament (EXETER BOOK) is the first poem in Old English to present a strophic form and a constant refrain and, in doing so, it plants the seeds of a future lyric poetry in English literature. It would be of paramount importance in the formation of modern England, vide Edmund Spenser's poetry during the Elizabethan Age and the development of the English democracy after the Second Civil War, which is represented the best by Milton's poetry.

Still approaching the Old English literature, two epic poems and some religious verses helped to give England a sense of nation and a national spirit. On the one hand, Beowulf and The Battle of Maldon deserve some reverence for their contribution in consolidating Christianity as the official religion of England and providing the country with its first and solid historical accounts.

Beowulf is the longest of the old poems with 3183 lines. As England of that time is a country still to be made, there are some controversies about Beowulf's home and setting. However, the debates come to the conclusion that, in the early national poetry, the references and allusions are Continental or Scandinavian. There is a general consensus among the critics and literary historians that Beowulf is not originally written in Anglo-Saxon dialect; thus, it is a piece of translation. The ideological result of such translation is that it turns the heathen 'stuff' into.

Christian sentiments and reflections. In terms of historical backgrounds, George Samuel stresses in The Concise Cambridge History of English Literature that

The poem gives us glimpses of the communal life of our ancestors in the hall of their lord, and tells of the emotions that moved them. They were brave; but they were terror-haunted.

Against the beasts they could fight; against the dim, impalpable unknown they were helpless. The long nights of the northern winter harrowed them with fear and wonder. ${ }^{1}$

As Beowulf has neither English theme nor setting, its most important feature in terms of contribution to the English national spirit lies in the fact that the poem depicts the world of the English ancestors. In the view of Michael Alexander, Beowulf shows

The heroic world of the north, a world both glorious and heathen. Dynasties take their identity from their ancestors, and the rulers of the English Kingdoms ruled by right of ancestral conquest. ${ }^{2}$

Among the religious verses, few pieces written by Caedmon have survived but it is attributed to him the deed of using English oral productions to wrap sacred stories in verse. It is historically established that Caedmon is the first English poet and that his verses have spiritual topics as their material. However, the references to Caedmon's work we have derive from Bede's Ecclesiastical History. Bede informs us that Caedmon lived in a monastery at Whitby. Bede's records underline that Caedmon once had a vision, probably a dream-vision, in which he was asked to chant God's deeds.

Bede also points out that Caedmon wrote in verses the stories of Genesis, Exodus and Daniel. Yet some modern scholars have brought new light to the texts, showing that they were not originally written by Caedmon. What is admitted by modern researchers is that Caedmon's oral productions were later used by singers or poets, who kept the spirit of the songs Caedmon had produced.

Anyway, the songs and the Christian poems attributed to Caedmon or his followers are historically important for providing the English Christianity with its earlier canon. As England is a country whose history proves that she is always reinventing herself, the first known English poet is Aldhelm. He lived during the time of King Alfred who used to think that Aldhelm was the best poet and had no rival in any national language. 
King Alfred, who is regarded as the Father of the English Navy, purveyed his country with good educational policies by contracting professors and scholars from the continent to educate his people. As a result, there was an improvement on the levels of literacy, which would have an impact on the reading and writing of the English language. It is also attributed to King Alfred the writing of the Anglo-Saxon Chronicle, at least its beginnings. His Chronicle was recorded by the monks and it would then function as the English historiography from Alfred's time to the eve of the ascension of Henry II to the throne.

The importance of the Anglo-Saxon Chronicle goes beyond the historiographical sphere if we take into consideration that it stands for a solid piece of Old English prose and, as such, it is a literary work which provides basis for a nation in its process of making. It is also considered a landmark in the transitional phase from Old to Middle English. Bede, another famous poet of that time, is responsible for the introduction of the expression Anno Domini (A.D.) in English and his work Ecclesiastical History of the English Race was translated to Old English by King Alfred himself and both authors contributed to the development of the English prose and forged the beginning of the memories of the country.

The second phase of the English language is called "Middle English" (1100-1500) and the greatest name of that period is Geoffrey Chaucer. The English literature of the late Middle Ages is neither an oral tradition, as in the time of Caedmon and Cynewulf, nor is it written in the Old English format. The English language that has evolved from Anglo-Saxon still lacks linguistic accuracy and a literary canon.

During the reign of King Richard II, the literature nourished in the English verse romance has in Sir Gawain and the Green Knight one of its finest expressions. Sir Gawain was discovered in a manuscript along with three other poems, Patience, Cleanness and Pearl. They were all written in alliterative verse in the Cheshire dialect, which suggests that they were creations of the same author or group. The historical importance of those writings consists in the fact that they helped England to shape her own mythology and this set of ideas has always been in the root of any national consciousness. The content of Sir Gawain blends chivalrous deeds, typical of King Arthur's legends, with Christian morality and its defense of the weak and most oppressed. There is an outrageous challenge to the Knights of the Round Table who ride in the quest, have a host of adventures and a fearful last meeting before returning to Camelot.

After the period of emergence of the Arthurian mythology, Geoffrey Chaucer, "The Father of the English Poetry", appeared. He was born in London and had a fine education. He studied the sciences and the arts of his time besides traveling across the continent, especially to France and Italy where he was appointed an ambassador. During his days, England was at war against France, the Hundred Years War, not to mention that the Black Death, the Peasant's Revolt as well as some other rebellions which made up the historical background.

Yet the greatest contributions Chaucer gave his country through his literary productions were in the fields of social psychology and language. In both cases, the literary work behind the facts is the same, i.e., The Canterbury Tales. In The Prologue, we have a glimpse of the climate, the weather and the exuberance of the English nature during the Spring, as it is described in the following verse: "Whan Aprille with his shoures swote..." (When April with his sweet showers...). ${ }^{3}$

After it, Chaucer presents a social profile of the English Middle Ages with its people and their strange professions. In the narrative, each one speaks with his/her own voice, as the Miller, the Wyf,

\footnotetext{
${ }^{1}$ SAMPSON, George. The Concise History of English Literature. Cambridge: C.U.P., ed. 1994. p. 24

${ }^{2}$ ALEXANDER, Michael. A History of English Literature. London: MacMillan Foundation, 2000. p. 27.

${ }^{3}$ CHAUCER, Geoffrey. The Canterbury Tales. New York: A Bantam Books, ed. 1990. p. 3.
} 
the Knight, the Prioress, the Merchant, etc. The colors, the mentality, the humor and everything concerning physical aspects are depicted in the narrative of each character. In introducing each of them, the "I" narrator points out the main psychological features of the characters, their position in the social rank and portrays the emergence of the English middle class.

The Canterbury Tales is regarded as the first literary work in English to present life as it is really lived. As a historical document, this work gives us an idea about the religiosity of the English people of that time and shows Canterbury as the center of the English Christianity. The pilgrimage described in the work goes beyond the presentation of the social and psychological profile of the English characters, besides that it shows how the faith in Christianity has been spread all across the country and how it provides the English people with a sense of national cohesion.

In terms of language, the English society of that time experienced bilingualism in the court. Parisian French was the predominant tongue of the nobles but the aristocrats had English as their vernacular. Like all new languages, English was still developing and would not take long to displace Norman French, the official language since William I, as the official language of the country. Given this fact, Henry III was the first King to use it in a Royal Proclamation in 1258. As a consequence, Norman French was no longer used as an intermediate language in the teaching of Latin, then the interlingua. Even the Law Court began operating in English.

Literature made a great contribution to the establishment of English as a national language once the writers who published their books by the $15^{\text {th }}$ Century introduced 'prologues' in their texts in order to defend the usage of English as a literary means of expression. Thus, it is quite important to underscore that Chaucer's literary works, which were written in the Eastland dialect of the London area, were decisive for the establishment of Standard English. Anthony Burgess teaches us in his English Literature that Chaucer's work is responsible for the introduction of phrases like "Murder will out", "The smiler with the knife beneath his cloak" and "Gladly would he learn and gladly teach"4. These facts were contemporaneous with the invention of the printing press and these events prepared the ground for the greatest changes to come in language, literature and nation.

The third phase of the English language is called "Modern English" (1500 - up to our days). The historical period we call the Elizabethan Age corresponds to the European Renaissance, a time when new conceptions of art and thought flourished from Italy to England. During those days, the dialect of the South, including the areas of London, Oxford and Cambridge was already consecrated as Standard English and totally national.

At the same time, Queen Elizabeth I was regarded as the protector of the artists and many of them put their craft in service of paying tribute to Her Majesty. In the English imaginary, she took the crown from Virgin Mary and she was considered as such. This worship was connected to the political and cultural systems of that time. The establishment of the first colonies overseas, especially in America, where the settlements of Virginia and Massachusetts Bay Colony, brought new economic perspectives to England, not to mention the development of the English imagination through stories and chronicles about the adventures of the English in the New World were other historical facts of great magnitude.

Three other historical events allowed England to gain ground in the European scenario. The first one was the victory of the English Navy over the Spanish Armada in 1588; the second was the coronation of James I, who poised England to empire and, finally, the Reformation took place. 
In that time, the state and the Roman Church got apart. It is important to stress that England played a new role in the international arena and this panorama addressed to a new era in English literature, particularly in its poetry and drama. It is commonly agreed, among the critics and literary historians, that Christopher Marlowe, William Shakespeare and Benjamin Johnson are the three most representative playwrights of the time, as well as Edmund Spenser, Shakespeare and Philip Sidney are accounted as the best poets of the era.

According to literary historians, no other poet contributed more for the prestige of English as a national language and its spread in the international arena than Edmund Spenser. On the one hand, he looked back to Chaucer to reaffirm the rising of a tradition in English verse. On the other, he was able to pick up the vogues of his time, i.e., Classicism, the Medieval Culture and Humanism and condensed them to shape his own poetry.

In embracing Protestantism, Chaucer's poetry and the English taste for eclogues and pastorals, Spenser helped to solidify the national spirit. At the same time, he sang in The Shepherd's Calendar the deeds of the English overseas. Today, when we regard his poetry in retrospect, we figure out how the imagination of the English people had an enlargement with the settlement of the first colonies abroad, especially in America. Spenser was aware and updated with the national issues of his time. According to David Daiches,

$$
\begin{aligned}
& \text { Indeed, he never withdrew from contemporary religious and political controversies } \\
& \text { into an unreal world of the imagination: he was always concerned with the problems } \\
& \text { of his day, as well as with broader issues and the Fairie Queene } \\
& \text { itself is an allegorical commentary on the religious, political, and social scene as well } \\
& \text { as a more general poetic exploration of the nature of virtue. }
\end{aligned}
$$

After the epochs of Queen Elizabeth I and King James I, England was a modern country with its own political, judicial, linguistic and cultural systems already established. However, the $17^{\text {th }}$ Century would pose a threat to England as a nation: the Civil War between Charles I and Parliament led by Cromwell, which began in 1642 and lasted until 1646; it was followed by another Civil War, from 1648 to 1651 . One more time a great poet was behind the major national issue: John Milton. Second only after Shakespeare in the history of English literature, Milton wrote pamphlets in order to support Cromwell and he was made a Minister during the short period of Republicanism in England.

When monarchy was restored and Charles II ascended to the throne, Milton became unpopular, but his poetical legacy would endure. On the one hand, Paradise Lost, L'Allegro and Il Penseroso, plus his sonnets guaranteed him a high-ranking in the literary history of England. On the other hand, Milton contributed to the growth of Democracy in his country, as the monarchical system had to pay the price for attributing power to Parliament.

Today, England is one of the greatest nations of all history and such condition is accounted for not only by its leaders, politicians, the military, scientists, musicians and philosophers, but also the poets in special.

\footnotetext{
${ }^{5}$ DAICHES, David. A Critical History of English Literature. IV vols. London: The Ronald Press Co., 1960. p. 175.
} 


\section{The American experience}

if literature played an important role in the formation of the English nation, the picture would not be different in the United States of America. In $18^{\text {th }}$ Century America, literature was still linked to history and the so-called "Founding Fathers" were responsible for the most proficient writings. During the War of Independence, Thomas Jefferson wrote, in collaboration with others, The Declaration of Independence, which was finally signed on the fourth of July, 1776.

At the core of The Declaration of Independence, Jefferson stresses that "all men are created equal" 6 . This statement per se established the basis of American democracy and its echoes have been heard up to our days.

Jefferson was not only responsible for establishing the basis of American democracy through the memorable literary piece that is the Declaration of Independence. As the third President of the country, he led in a critical and decisive moment of its history, from 1800- 1808. During his administration, he demonstrated his view of the future and his boldness as he doubled the size of the nation by purchasing the huge territory of Louisiana from Napoleon. In doing so, Jefferson appointed to the path for the American development in territory, richness, challenges and spirit.

The expansion towards the West boosted the creativity of many American writers who saw in the process of internal colonization an inexhaustible source of material for literary expression. Each new step the Pioneers took in the wilderness, a new natural element was discovered and had to be described in prose, music or poetry. Even the English language expanded its lexicon with the American experience, taking into account that America had flowers, birds, animals and natives that were completely unknown in the British Isles. Thus, the language needed to be enlarged in order to name them.

Another factor that contributed to the development of a national literature was the growth of prosperity. The industry developed faster in the Northern states where the ship factories in New York and New England were flourishing. The important rivers of Mississippi and Ohio had been crossed by steamboats and the invention of the cotton gin increased the production of cotton in the South, allowing the country to multiply its exports. Consequently, the cities along the East Seaboard grew in all aspects, from size through prosperity, from education through the interest in arts and literature. And it is exactly literature the social segment which would provide the nation with its spirit of greatness.

Some decades after the independence, when the American nation was still in the process of making, a literary movement set in New York City demanded the construction of the national cultural identity, such movement was called the "Knickerbockers". Among its most important mentors, two writers deserve mentioning: Washington Irving and James Fenimore Cooper. Despite writing under the influence of the European culture, Irving aimed to provide American literature with a local color, especially for his part of the nation, the New York area and the Hudson Valley. Irving's attempts were so successful that even today his tales Rip Van Winkle and The Legend of Sleepy Hollow are studied by High School students.

James Fenimore Cooper wanted to write to all America and his works were contemporary with the advance of the American frontiers towards the West. Cooper seized the opportunity and portrayed in his novels the process of internal colonization. It is important to argue that Cooper used his native New York state as a metonymy for all the United States. In his novels The Pioneers, The Last of the Mohicans, The Prairie, The Pathfinder and others, Cooper describes all kinds of Americans, from the Yankee sailors to the Indians, from the Pioneers to the African-Americans. Those efforts are sided

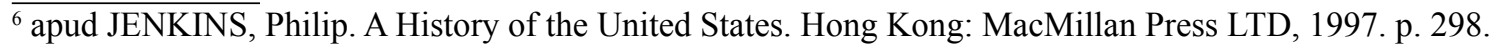


with his failure in describing the American women. Anyway, the Knickerbockers understood that the process of making a nation should have had a counterpart in the building of a national literature and their efforts were not in vain.

As time went by, the country expanded towards the Pacific Coast but the feeling that the national culture had remained along the East Seaboard prevailed. Many critics and literary historians, like Peter B. High, believe that "the cultures of Massachusetts and Virginia ought to be the models of national

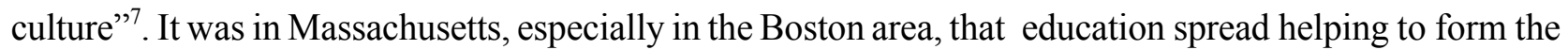
ideological and literary consciousness of the New Englanders. Then, Harvard University was founded and many intellectual journals, such as "North American Review", began to circulate. Some societies like "Useful Knowledge Society", "Natural History Society" and "The Mercantile Library Association" were founded. As a consequence, many local intellectuals became lecture-goers.

Parallel to that cultural agitation, a "spiritual" movement emerged in the Boston area and set the new tone in American Belles-Letters: Transcendentalism. Its greatest mentor and philosopher was also a great poet: Ralph Waldo Emerson. He was destined to "declare" the literary independence of the United States. Emerson and his disciple Henry David Thoreau were more interested in the individual and, given this reasoning, they ratified the main premise of American democracy, i.e., the realm of the individual. The transcendentalists' credo is clearly expressed in Emerson's essay Nature and in Thoreau's Civil Disobedience. Their confidence in the future of America as a great nation is also expressed in Emerson's The American Scholar and Self-Reliance, in which he attacks the old ideas and tradition inherited from the Europeans and points the way towards a great future.

Transcendentalism brought the literary scene back to Boston and provided the city with a local color and, at the same time, gave the nation an aura of universal civilization due to its links to Plato's philosophy, English and German Romanticism and Oriental religions.

It was not by chance that Transcendentalism had Boston as its main stronghold. The city, which was also the cradle of the independence of the United States with the historic episode known as Boston Tea Party, was also the most advanced center in education. Besides Harvard, then the most renowned college in America, the foundation and spread of many scientific societies and literary clubs provided the adequate atmosphere for the development of a literary movement with cosmopolitan features.

It is undeniable that New England, with Boston at its hub, was the most intellectual region of the country. Thus, that area bolstered up the national consciousness for the social issues of the time. On the one side, feminism took its first steps in the U.S. with the militancy of female writers like Margaret Fuller and Harriet Beecher Stowe, the latter being the author of Uncle Tom's Cabin, a novel that set the nation on fire for the Abolitionist cause. On the other side, New England's poets and writers played a very important role in the Abolitionist Campaign and gave support to the Federal cause during the Civil War.

In between the emergence of Transcendentalism and the Civil War, a writer from New York, Herman Melville, launched a novel in 1851 which depicts the democratic spirit of America with epic flavor: Moby Dick. On the surface, it is a romantic narrative teemed with adventures of the crew of the Pequod during a series of whale-hunting set at the open seas. Yet it has been clear, since the beginning, that it is a symbolic voyage through which Melville presents his view of the world based on dichotomy. The tonic is the conflict between the light and the dark. The former is represented by the White Whale Moby Dick, whereas Captain Ahab stands for the latter.

Albeit the symbolic conflict addresses to the entire destruction still to come by the end of the novel, which leaves only the narrator, Ishmael, who tells us the story. Moby Dick's characters are representative 
of the ethnic groups that shape the American society. Besides Ishmael and Ahab, there are three other New Englanders: Starbuck, Stubb and Flask. Among the harpooners, two come from the minority groups, including the Indian Tashtego, and the Polynesian Queequeg represents the immigrants. Dagoo, of African origin and Pip, the African- American boy, complete the crew.

The contrast between Queeqeg's primitive pagan morality and the conventional Christian faith of Starbuck can be read as the democratic diversity of religious conceptions that take place in the U.S.A. The vastness of the ocean symbolizes the freedom of enterprise that has characterized the American society since its beginnings. If the destruction of the Pequod and the death of all crew but Ishmael at the end of the novel can be seen as Melville's pessimism and his disbelief in the individual identity, the survival of Ishmael will allow me to read it as a kind of belief that the human salvation lies in art, especially in the art of telling stories, i.e., literature. All in all, Moby Dick is ranked by the most important critics and literary historians as the greatest novel of American literature.

Nevertheless, the confidence in America as a nation was shaken and a real threat to its existence was posed by the Southern states, which attempted to secede and form the Confederate States of America. The split of the country lingered on during the four years of a cruel and harsh Civil War from 1861 through 1865. President Lincoln and Generals Ulysses Grant and William T. Sherman were on the side of the Northern heroes who would win the war. Adding to that, a great poet, a late transcendentalist, would also become a hero, Walt Whitman. Whitman published Leaves of Grass in 1855 and would re-edit it to insert new poetical material until 1892. During the Civil War, he served as a nurse in the battlefields of Virginia.

It is remarkable to note that Whitman's book develops and changes in parallel with the growth of his country. His faith that America would be a great nation lies in his belief that such accomplishment would be made by the American people. He stresses in I Hear America singing that

\footnotetext{
I hear America singing, the varied carols I hear, those of mechanics, each one singing his as it should be blithe and strong, the carpenter singing his as he measures his plank or beam....
}

One of the functions of the $19^{\text {th }}$ Century literature in the New World was to introduce the country to its own fellows, considering that, in that time, the means of transportation from one region to another was scarce and available to just a few and the communication systems _. Leaves of Grass. New York: Barnes had not been developed yet. Given these circumstances, a novel like The Adventures of Huckleberry Finn, by Mark Twain, introduces the frontier of the Mid-West and the South to the imaginary of the people from the other parts of the U.S.A.

Despite the story turning around Huck and his friend, the fugitive slave Jim, the two main characters share this position with the Mississippi River. It is the river which is present in the national imaginary as the river of national integration linking the north to the south and the east to the west. It is the river which directs the adventures of Huck and Jim and sets up life in towns that grow along its margins. But it is important to underscore that The Adventures of Huckleberry Finn is much more than a boy-book or juvenilia. It deals with moral and philosophical issues inserted into Huck's mind. In spite of being an innocent boy, Huck reasons deeply about Jim's condition as a slave and decides not to return him to slavery but, instead, to go with him along the river.

Huck is a boy of nature who flees from Widow Douglas and her attempts at getting him civilized. Mark Twain presents through Huck's rejection of becoming civilized more than the evil and social pains caused by the feuds of that civilization, but the essence of slave Jim as a human being. The ${ }^{8}$ WHITMAN, Walt. “I Hear America Singing” In: and Noble Classics, ed. 1993. p. 10. 
main point of the narrative lies in Huck and Jim's commitment to remaining together and leading their adventurous life based on the course of the river. Twain, in providing them with such freedom, shows that he also prefers following the mythic power of nature.

Thus, Dudley Miles and Robert C. Pooley, in their approach to the novel in Literature and Life in America, argue that

Huck's wanderings, filled with endless incident, bring before us every type of the frontier. Mrs. Judith Loftus, who starts Huck and Jim down the river on the June flood, remains a warm and living creation, an unforgettable representative of those shrewd, capable pioneer women who helped to build a nation.

\section{Conclusions}

In the threshold of this new millennium in which we live, many people may think that the national identities of England and the United States are taken for granted. However, the first conclusion I came to after approaching their national spirit through literature is that their cultural identity, as well as that of any other nation, is a permanent process, an open book waiting for its content to be written.

At any specific time, a country may have its national identity renewed so that it fulfills the expectations of the new generations and faces the challenges made by history. This is the reason why England remade its trajectory renewing its educational system, its labor policy and foreign affairs, besides improving its political forms of representation and becoming more updated and democratic. As a consequence, English literature has contributed to shape Twentieth-Century and Twenty-First-Century England, recording the deeds of the English in two world wars and the decline of the empire. Another fact of great impact is the turning of English literature into Literature in English, which has allowed literature to purvey body and soul for the post-colonial national expressions all over the world.

The same phenomenon may be verified in the early Twentieth-Century America, when the country was obliged to reinvent itself in order to reach the top. The U.S. entered the $20^{\text {th }}$ Century as the most industrialized nation of the world with a big list of inventions, namely: the railroads, cars, planes and others, not to mention the advances in science, technology and medicine. Consequently, the material progress demanded a spiritual counterpart and American literature, one more time, would fill in the gap.

In the 1920s, the so-called "Lost Generation" set the literature of the United States as first rank in the international scenario with a host of geniuses like Hemingway, Faulkner, Fitzgerald, Dos Passos, Cummings, Gertrude Stein and others, who are worldwide recognized.

The Southern tradition raised its voice with the movement entitled "New Criticism" in the 1930s, showing the country and the world that the golden aura of American literature had been expanding. The 1940s and 1950s witnessed the internationalization of American literature, which would increase its scope with the growth of new branches like "The Jewish American literature" and "The African-American one". The incredible flow continued in the 1960s and 1970s with the emergence of post-modern literature, helping to shape the new soul of America. From Norman Mailer, Thomas Wolfe, Edward Albee to Toni Morrison, Alice Walker, Don Dellilo and also the emergence of new segments like "Feminism", "The Vietnam War literature" and "The Asian-American literature", the life of the United States has been recorded, renewed, criticized and has improved through its literature.

To finish, I think those brief accounts are enough to show how important literature is for shaping the spiritual, social, psychological and artistic profile of any nation and, in the end, the treasures are ours to share.

Recebido em: 07/10/2015

Aprovado em: 15/07/2016

${ }^{9}$ MILES, Dudley \& POOLEY, Robert C. Literature and Life in America. Chicago: Scott, Foresmanand Company, 1948. p. 293. 